\title{
Serum bactericidal activity as indicator of innate immunity in pacu Piaractus mesopotamicus (Holmberg, 1887)
}

\author{
[Atividade bactericida do soro como indicador de imunidade inata de pacu \\ Piaractus mesopotamicus (Holmberg, 1887)] \\ J.D. Biller-Takahashi ${ }^{1}$, L.S. Takahashi ${ }^{2}$, F. Pilarski ${ }^{3}$, F.A. Sebastião ${ }^{3}$, E.C. Urbinati ${ }^{1}$ \\ ${ }^{1}$ Universidade Estadual Paulista (Unesp) - Jaboticabal, SP \\ ${ }^{2}$ Faculdade de Zootecnia - Universidade Estadual Paulista (Unesp) - Dracena, SP
}

\begin{abstract}
The immune system of teleost fish has mechanisms responsible for the defense against bacteria through protective proteins in several tissues. The protein action can be evaluated by serum bactericidal activity and this is an important tool to analyze the immune system. Pacu, Piaractus mesopotamicus, is one of the most important fish in national aquaculture. However there is a lack of studies on its immune responses. In order to standardize and assess the accuracy of the serum bactericidal activity assay, fish were briefly challenged with Aeromonas hydrophila and sampled one week after the challenge. The bacterial infection increased the concentration of protective proteins, resulting in a decrease of colony-forming unit values expressed as well as an enhanced serum bactericidal activity. The protocol showed a reliable assay, appropriate to determine the serum bactericidal activity of pacu in the present experimental conditions.
\end{abstract}

Keywords: fish innate immunology, methodology, humoral immunity

\section{RESUMO}

O sistema imune de peixes teleósteos tem mecanismos responsáveis pela defesa contra bactérias e atua através de proteínas presentes em diversos tecidos. A ação destas proteínas pode ser avaliada pela atividade bactericida do soro, sendo esta uma importante ferramenta para analisar o sistema imune. $O$ pacu, Piaractus mesopotamicus, é um peixe nativo muito importante para aquicultura nacional, entretanto há pouco conhecimento sobre o funcionamento de seu sistema imune. Assim foi realizado experimento para padronizar e avaliar a eficiência do ensaio de atividade bactericida. Resumidamente, peixes foram desafiados por Aeromonas hydrophila e amostradas uma semana após o desafio. A infecção bacteriana promoveu um aumento na concentração de proteínas protetoras, resultando em diminuição dos valores de unidades formadoras de colônias ou expressos também como aumento da atividade bactericida do soro. O protocolo se mostrou confiável, sendo apropriado para determinar a atividade bactericida do soro de pacu nas condições experimentais.

Palavras-chave: imunologia inata de peixes, metodologia, imunidade humoral

\section{INTRODUCTION}

The innate immunity possibly that has been originated in unicellular organisms during the evolutionary period is considered the oldest system in the phylogenetic scale. This system identifies regions in molecules called Pamps Pathogen associated molecular patterns, from microorganisms such as lipopolysaccharide,

Recebido em 21 de maio de 2012

Aceito em 5 de maio de 2013

E-mail: jaque.biller@yahoo.com.br peptidoglycan, bacterial DNA or viral RNA, or other molecules found in multicellular organism membranes known as "non-self", but do not identify the components of the body itself. The Pamps are generally highly preserved fractions and are present in the greater part of microorganisms. Conversely, the specific system first appeared about 450 million years ago, and can be found in all vertebrates except in fish of the Agnatha class. The acquired system receptors 
are responsible for detecting the pathogenic agent, and can be found in the cell membrane of $\mathrm{T}$ lymphocytes (TCR $-\mathrm{T}$ cell receptor) and $\mathrm{B}$ lymphocytes (BCR, B cell receptor, also called a membrane immunoglobulin) or in serum as free antibody (Holland and Lambris, 2002; Abbas and Litchman, 2004; Boltaña et al., 2011).

The immune system of teleost fish has mechanisms responsible for the defense against bacteria, through humoral and cell-mediated pathways, which act in a multifactorial approach so as to prevent bacterial colonization. Innate mechanisms against bacterial invasion include the production of antibacterial compounds, such as proteins of the complement activated by an alternative pathway, acute phase proteins, cytokines, and phagocytosis and inflammation (Ellis, 2001; Garcia et al., 2012).

Proteins of the complement system activated by alternative pathways are considered the most effective antibacterial compounds due to their lytic activity, proinflammatory chemotaxis and opsonizing action that influence the defense cell response. Regarding phagocytes, neutrophils and macrophages are very important because of their large quantities of lysosomal enzymes and the production of reactive oxygen species responsible for the destruction of invading bacteria (Ellis, 1999, Biller et al., 2012).

Bacteria growth inhibition factors are essential to prevent tissue damage. Among these factors, the transferrin, a soluble blood protein with high iron affinity is present in high concentration mainly in the acute inflammation phase so as to activate macrophages and decrease the available iron, an essential ion for some bacteria in infection establishment. In addition, antiproteases, such as lectins, are blood proteins which act on the proteolytic compound of bacteria responsible for the lysis of fish tissue. Lectins generate pathogen agglutination due to its high affinity to certain carbohydrates on the bacteria wall (Bullen and Griffiths, 1987; Arason, 1996; Bayne and Gerwick, 2001; Stafford and Belosevic, 2003; Salinas et al., 2011).

Lysines, found in blood and body tissue, mainly where there are leukocytes (especially monocytes and neutrophils) are antibacterial peptides that attack pathogen membranes. Among lysines, lysozyme lyses peptidoglycan components of Gram-positive and Gramnegative bacteria walls; C-reactive protein binds to phosphorylcholine of the microorganisms walls and may increase its concentration after a heat shock, inflammatory agents, and during warm periods of the year besides promoting the activation of complement and phagocytosis (Murray and Fletcher, 1976; Nakanishi et al., 1991; Yano, 1996; Ellis, 1999, 2001; Magnadottir, 2011).

The presence of protective proteins in fish blood can be evaluated by serum bactericidal activity and this is an important tool to analyze the innate immune system. The standardization of techniques in order to assess the indicators of fish immunity is highly valuable for National aquaculture survey. Regarding pacu, Piaractus mesopotamicus (Holmberg, 1887), it is one of the most important fish in national aquaculture, however there is a lack of studies on its immune responses (Abreu et al., 2009; Martins et al., 2009; Sado et al., 2010; Biller et al., 2012; Biller et al., 2013). In addition, the pathogenic agent used in the challenge is an important bacterium that causes severe disease outbreaks in Brazilian aquaculture and worldwide (Biller et al., 2014). This work has standardized the methodology for evaluation of serum bactericidal activity of pacu, after the Aeromonas hydrophila challenge.

\section{MATERIAL AND METHODS}

A total of 144 pacu (Piaractus mesopotamicus) (Holmberg, 1887) $(205.4 \pm 47.0 \mathrm{~g} ; 15.21 \pm 1.44 \mathrm{~cm})$ were distributed in 18 tanks with 1001 capacity ( 8 fish per tank) with a continuous water flow system and aerated with compressed air diffused through air stones. The water quality parameters were monitored daily and were within the values described for the species (Urbinati et al., 2010): temperature $27.65 \pm 0.38^{\circ} \mathrm{C}$; dissolved oxygen $5.08 \pm 0.49 \mathrm{mg}^{-1}$ and $\mathrm{pH} 7.76 \pm 0.07$. Fish remained in these conditions during 20 days for acclimatization, being fed to apparent satiation twice a day with a commercial diet $(28 \%$ protein, $3 \%$ fat, $1 \%$ fiber).

Fish were randomly distributed into two treatment groups, each one in nine tanks. After the acclimatization, fish were sampled before bacterial challenge (Before Challenge-BC) and after bacterial challenge (After Challenge-AC). Two fish from each tank from the BC group 
$(\mathrm{n}=18)$ were been anesthetized (benzocaine in alcoholic solution, $0.1 \mathrm{~g} \mathrm{~L}^{-1}$ ) and their blood collected from caudal vasculature, followed by biometrics. Sampled fish were not reusable and they were taken out of the experiment. Two fish from each tank from the AC group $(n=18)$ were anesthetized and inoculated with $A$. hydrophila. The bacterial suspension was inoculated into the abdominal cavity by intraperitoneal injection. After this procedure, fish were kept in their tanks and fed a commercial diet during seven days, in the same condition of acclimatization period, and then sampled and bled for serum extraction. Serum was stored at $-70^{\circ} \mathrm{C}$ until use in order to preserve thermo labile proteins.

The bacteria used in the challenge were obtained according to Garcia and Moraes (2009) and Garcia et al. (2009), briefly, an Aeromonas hydrophila strain from Laboratório de Patologia de Organismos Aquáticos (LAPOA-CAUNESPJaboticabal) (Genbank identification as ATCC 7966-http://www.ncbi.nlm.nih.gov/genbank/) was cultured in liquid tryptone soya broth (TSB), at $25^{\circ} \mathrm{C}$, for $24 \mathrm{~h}$ incubation. After this period, the bacterial suspension was washed and centrifuged at $3000 \mathrm{~g}$ for three $\mathrm{min}$ in sterile phosphate buffer solution (PBS) $(\mathrm{NaCl}, 0.137 \mathrm{M} ; \mathrm{KCl}, 2.7$ $\mathrm{mM} ; \quad \mathrm{KH}_{2} \mathrm{PO}_{4}, \quad 1.5 \mathrm{mM} ; \quad \mathrm{Na}_{2} \mathrm{HPO}_{4}, \quad 8.1 \mathrm{mM}$; $\mathrm{CaCl}_{2}, 0.9 \mathrm{mM} ; \mathrm{MgCl}_{2}, 0.49 \mathrm{mM}$ in $1 \mathrm{~L}$ Milli-Q distilled water), with $\mathrm{pH} 7.4$, three times until complete TSB removal. The bacterial suspension was diluted in sterile PBS at a concentration of $1 \times 10^{8}$ colony forming units (CFU) according to the Mc Farland scale (Vandepitte et al., 1993).

Pacu serum was applied to standardize the methodology of bactericidal activity, adapted following Kajita et al. (1990), Rao et al. (2006) and Aly et al. (2008) and the challenge was promoted in order to increase antibacterial proteins. The bactericidal activity assay was assessed in sterile micro tubes, in which $40 \mu \mathrm{l}$ of A. hydrophila suspension and $40 \mu \mathrm{l}$ of pacu serum were incubated during $1 \mathrm{~h}$ at $37^{\circ} \mathrm{C}$. The same $A$. hydrophila strain, previously inoculated in fish, was applied in the assay at $1 \times 10^{8} \mathrm{CFU}$. After this procedure, the resultant suspension was cultured in tryptone soya agar (TSA) and plaques were incubated overnight at $25^{\circ} \mathrm{C}$, including a positive group that consisted of TSA plates containing bacteria and PBS suspension instead of fish serum. The positive group was integrated in the assay to confirm the serum action on bacteria. After $24 \mathrm{~h}$ of growth, the CFU were manually counted and values were expressed in values of CFU and serum bactericidal activity as the percentage of colony forming units in the test group to that in the positive group: 1- CFU/positive (\%) of pacu.

Serum biochemical parameters such as protein, albumin, globulin and A:G index were attempted to demonstrate the increased protective protein production. Total serum protein was evaluated by the Biuret method (Labtest Kit) (Reinhold, 1953) and albumin was determined by colorimetric assay of bromocresol green binding method (Labtest Kit) (Dumas et al., 1971). Globulin was determined by subtracting albumin from total serum protein and globulin-albumin ratio $(A: G)$ was estimated by dividing the value of albumin fraction by globulin fraction of each tested sample. Results were compared between $\mathrm{BC}$ and $\mathrm{AC}$ groups, and in this case no positive group was included.

Data were submitted to one-way ANOVA. If results were significant, Tukey test was applied for means comparison. Differences were considered significant at $\mathrm{P}<0.05$.

\section{RESULTS}

There was no mortality registered in fish post challenge, and after seven days serum were submitted to bactericidal activity, and therefore protective proteins were satisfactorily evaluated by counting CFU survivors. The results were expressed in two ways: the first one shown in Figure 1, expressed in CFU values, and the second one in Figure 2 expressed in serum bactericidal activity by [1- cfu/positive (\%)]. In Figure 1, the positive group (serum free) displayed the highest values, indicated by the largest bacterial growth, this result was expected once there were no serum to destroy bacteria, however, in $\mathrm{BC}$ and $\mathrm{AC}$ groups, the bacterial growth was reduced because of bactericidal ability in serum, mainly in the AC group $(p<0.05)$, when the lowest bacterial growth was observed. On the other hand, the result in Figure 2 showed the serum bactericidal activity of pacu. In that, the positive group (serum free) displayed zero activity once there was no serum, but in BC and $\mathrm{AC}$ groups, the bacterial activity increased, mainly in the AC group $(p<0.05)$, indicated by the higher serum bactericidal activity profile. 


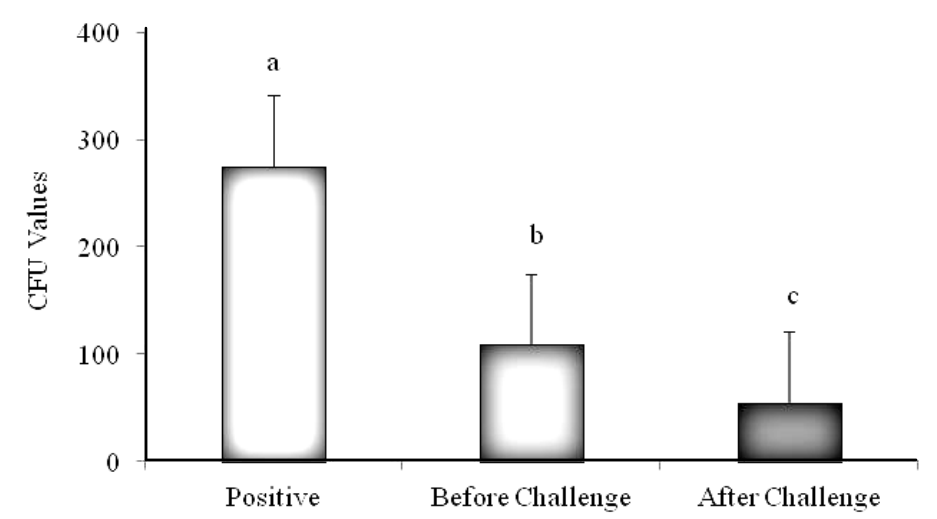

Figure 1. CFU value (mean \pm sd) of pacu after challenge trial. Significant differences are indicated by different letters $(\mathrm{p}<0.5)$.

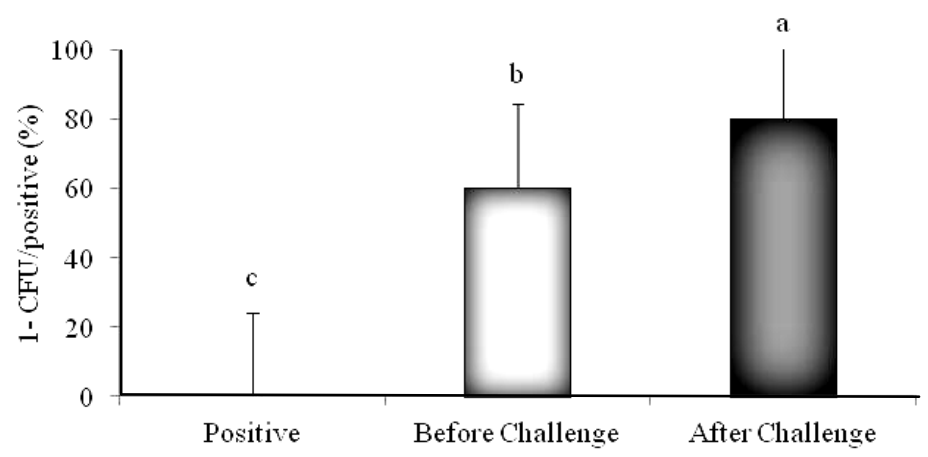

Figure 2. Serum bactericidal activity (1 - cfu/positive \%) (mean \pm sd) of pacu after challenge trial. Significant differences are indicated by different letters $(\mathrm{P}<0.5)$.

Once bactericidal proteins have enhanced, the serum biochemical parameters such as protein, albumin, globulin and $\mathrm{A}: \mathrm{G}$ index were determined to support the increased protective protein production. As shown in Table 1, the total serum protein and globulin concentration increased, indicating the raise in defense proteins.

Table 1. Serum biochemical assays (mean \pm sd) of pacu before and after challenge trial*

\begin{tabular}{lcc} 
& Before challenge & After challenge \\
\hline Protein $(\mathrm{g} / \mathrm{dL})$ & $3.638 \pm 0.2 \mathrm{~b}$ & $4.035 \pm 0.16 \mathrm{a}$ \\
Albumin $(\mathrm{g} / \mathrm{dL})$ & $1.041 \pm 0.20 \mathrm{a}$ & $1.168 \pm 0.05 \mathrm{a}$ \\
Globulin $(\mathrm{g} / \mathrm{dL})$ & $2.597 \pm 0.29 \mathrm{~b}$ & $2.866 \pm 0.13 \mathrm{a}$ \\
A:G index & $0.413 \pm 0.13 \mathrm{a}$ & $0.408 \pm 0.02 \mathrm{a}$ \\
\hline
\end{tabular}

*Significant differences are indicated by different letters $(\mathrm{p}<0.5)$.

\section{DISCUSSION}

The standardization of the technique for the evaluation of serum bactericidal activity as a response of the fish innate immune system has been properly carried out in this work. The antibacterial activity of blood serum is considered a nonspecific response to inhibit the growth of infectious microorganisms (Yano, 1996). The profile of serum response from pacu is shown in Figure 1 (CFU values) and in Figure 2 (serum bactericidal activity) and indicates that this is a reliable assay for immune studies in fish.

The presentation of CFU values is widely employed in various studies, such as in 
Hernandez et al. (2007) who evaluated the effects of vitamin A on serum anti-bacterial activity in the juvenile Japanese flounder, Paralichthys olivaceus. In addition, Aly et al. (2008) also assessed the serum bactericidal activity in order to determine the effects of Bacillus subtilis and Lactobacillus acidophilus as potential probiotics on Nile tilapia, Oreochromis niloticus. Rao et al. (2006) observed the effect of Achyranthes aspera on the immunity of Labeo rohita infected with A. hydrophila through this immune parameter. Similarly, Azza and Abd-El-Rhman (2009) described the effects of propolis and A. hydrophila infection on serum bactericidal activity of Nile tilapia. The CFU counting values in each study may be different due to their respective modifications and bacteria concentration applied in the challenge trial.

The serum bactericidal activity of pacu (Figure 2) evaluates fish responses in percentages. The challenged fish showed higher ability to destroy bacteria, compared with fish without the artificial infection. The bactericidal activity of the positive group is absent because of the lack of serum in protocol assay, contrasting control and challenge groups. In the positive group bacteria were suspended in PBS solution only.

The results presented in percentage of activity is commonly used, as in Misra et al. (2006) who assessed the bactericidal activity to observe the effect of $\beta$-glucan in Labeo rohita fingerlings and in Misra et al. (2009) who also applied the assay to evaluate the bactericidal activity after a long-term administration of levamisole to the same fish. Das et al. (2009) used the same protocol in a study to examine the effect of Euglena viridis on the immune response of $L$. rohita.

The increased serum bactericidal activity detected after the challenge in this work (Figure 2) demonstrates the raise of serum protective proteins that usually occurs after a natural infection, such as in disease outbreaks, or in artificial infections, such as after vaccination and challenge. These proteins are known as inflammation acute phase proteins. Increased acute phase proteins can also occur immediately after infection or injury, involving changes in hepatic, neuro-endocrine and immune systems. The presence of injury (damage in cell membrane, with tissue factors and arachidonic acid metabolites release) or pathogen affect the release of inflammatory cytokines such as interleukin 1 (IL-1), interleukin 6 (IL-6) and tumor necrosis factor $\alpha(\mathrm{TNF}-\alpha)$, that are proteins synthesized by the liver, encephalon or immune cells which act in tissue reparation, homeostasis maintenance and innate and acquired system modulation (Bayne and Gerwick, 2001; Magnadottir et al., 2011).

There are many protocols to evaluate the bacterial killing ability, however, the procedure applied in this assessment is more interesting than that applied by several researchers such as Chen and Ainsworth (1992) since this trial was carried out with serum in order to assess bacterial killing ability produced by treatments. The Chen and Ainsworth (1992) methodology of the bacterial killing assay uses a macrophage suspension instead of serum, where cells act the same way as the serum, destroying the CFU and promoting decrease in its numbers in the plates. The advantage of this study is due to the use of serum as an agent for CFU destruction, given that the entire procedure of cell preparation is laborious and delicate.

Likewise, Costa et al. (2011) applied a different protocol in order to evaluate the effect of vaccination against yersiniosis on Atlantic salmon in which the serum bactericidal activity were assessed in lawn method on TSA plates that were prepared by swab inoculation using a cell suspension, and the bactericidal activity was recorded as positive or negative.

Since bactericidal proteins have enhanced, the serum biochemical parameters such as protein, albumin, globulin and A:G index were determined to prove the increased protective protein production after a challenge. Among total serum proteins, globulins correspond to proteins present in blood responsible for the organism's defense, such as immunoglobulins, proteins of the complement activated by alternative pathways, acute phase proteins, cytokines, lysozyme, transferrin and lectins. In the present study the increase in total serum protein and globulin indicate the raise in protective proteins after the challenge and can be correlated to the serum bactericidal activity (Murray and Fletcher, 1976; Arason, 1996, Ellis 1999, 2001, Magnadottir, 2006; Maqsood et al., 2009). Hereby, it can be understood that the National 
survey can count on a reliable and cheap assay to evaluate the fish innate immunity, once this area of knowledge has been deeply studied and there are a lack of tools to assess those parameters.

\section{CONCLUSIONS}

Serum bactericidal activity is an important parameter in immunology studies due to its ability to evaluate innate defense systems since the immune system responses may be influenced or manipulated by several substances or processes. The increase of this parameter in the present study is a result of pathogen detection by innate system, which has prompted acute phase proteins so as to protect fish against invading microorganisms. This work has first assessed the serum bactericidal activity of native fish, and has standardized an important methodology for studies of immunology in Brazilians fish.

\section{ACKNOWLEDGMENTS}

This study was granted by $\mathrm{CNPq}$ (Conselho Nacional de Desenvolvimento Científico e Tecnológico) and CAPES (Coordenação de Aperfeiçoamento de Pessoal de Nível Superior).

\section{REFERENCES}

ABBAS, A.K.; LICHMAN, A.H. Basic Immunology. Functions and disorders of the immune system. 2004. $312 \mathrm{p}$

ABREU, J.S.; MARZOCCHI-MACHADO, C.M.; URBACZEK, A.C. et al. Leukocytes respiratory burst and lysozyme level in pacu (Piaractus mesopotamicus). Braz. J. Biol., v.69, p.1133-1139, 2009.

ALY, S.M.; AHMED, Y.A.; GHAREEB, A.A.A.; MOHAMED, M.F. Studies on Bacillus subtilis and Lactobacillus acidophilus, as potential probiotics, on the immune response and resistance of Tilapia nilotica (Oreochromis niloticus) to challenge infections. Fish Shellfish Immunol., v.25, p.128-136, 2008.

ARASON, G.J. Lectins as defence molecules in vertebrates and invertebrates. Fish Shellfish Immunol., v.6, p.277-289, 1996.

AZZA, M.M.; ABD-EL-RHMAN. Antagonism of Aeromonas hydrophila by propolis and its effect on the performance of Nile tilapia, Oreochromis niloticus. Fish Shellfish Immunol., v.27, p.454-459, 2009.
BAYNE，C.J.; GERWICK, L. The acute phase response and innate immunity of fish. Dev. Comp. Immunol., v.25, p.725-743, 2001.

BILLER-TAKAHASHI, J.D.; TAKAHASHI, L.S.; MARZOCCHI-MACHADO, C.M. et al. Hemolytic activity of alternative complement pathway as an indicator of innate immunity in pacu (Piaractus mesopotamicus). Rev. Bras. Zootec., v.41, p.237-241, 2012.

BILLER-TAKAHASHI，J.D.; TAKAHASHI， L.S.; SAITA, M.V. et al. Leukocytes respiratory burst activity as indicator of innate immunity of pacu Piaractus mesopotamicus. Braz. J. Biol., v.73, 2013.

BILLER-TAKAHASHI, J.D.; MONTASSIER, H.J.; TAKAHASHI, L.S.; URBINATI, E.C. Proposed method for agglutinating antibody titer analysis and its use as indicator of acquired immunity in pacu, Piaractus mesopotamicus. Braz. J. Biol., v.74, 2014.

BOLTAÑA, S.; ROHERA, N.; GOETZ, F.W.; MACKENZIE, S.A. PAMPs, PRRs and the genomics of gram negative bacterial recognition in fish. Dev. Comp. Immunol., v.35, p.1195-1203, 2011.

BULLEN, J.J.; GRIFFTHS, E. Iron and Infection Molecular, Physiological and Clinical Aspects. Chichester: Wiley, 1987. 515p.

CHEN, D.; AINSWORTH, A. Glucan administration potentiates immune defence mechanisms of channel cat fish, Ictalurus punctatus (Rafinesque). J. Fish Dis., v.15, p.295-304, 1992.

COSTA, A.A.; LEEF, M.J.; BRIDLE, A.R. et al. Effect of vaccination against yersiniosis on the relative percent survival, bactericidal and lysozyme response of Atlantic salmon, Salmo salar. Aquaculture, v.315, p.201-206, 2011.

DAS, B.K.; PRADHAN, J.; SAHU, S. The effect of Euglena viridis on immune response of rohu, Labeo rohita (Ham.). Fish Shellfish Immunol., v.26, p.871876, 2009

DUMAS, B.; WATSON, W.; BRIGGS, H. Albumin standards and the measurement of serum albumin with bromocersol green. Clinica Chim Acta, v.31, p.87-96, 1997.

ELLIS, A.E. Immunity to bacteria in fish. Fish Shellfish Immunol., v.9, p.291-308, 1999.

ELLIS, A.E. Innate host defense mechanism of fish against virus and bacteria. Dev. Comp. Immunol., v.25, p.827-839, 2001.

GARCIA, F.; MORAES, F.R. Hematologia e sinais clínicos de Piaractus mesopotamicus infectados experimentalmente com Aeromonas hydrophila. Acta Scient. - Biol. Scien., v.31, p.17-21, 2009. 
GARCIA, F; MORAES, F.R.; MARTINS, M.L. Challenge of pacu (Piaractus mesopotamicus) fed diets supplemented with vitamins $\mathrm{C}$ and $\mathrm{E}$ by Aeromonas hydrophila under different temperature. Arq. Bras. Med. Vet. Zootec., v.61, p.378-385, 2009.

GARCIA, F.; SCHALCH, S.H.C.; ONAKA, E.M. et al. Hematologia de tilápia-do-nilo alimentada com suplemento à base de algas frente a desafios de estresse agudo e crônico. Arq. Bras. Med. Vet. Zootec., v.64, p.198-204, 2012.

HERNANDEZ, L.H.H.; TESHIMA, S.; KOSHIO, S. et al. Effects of vitamin A on growth, serum antibacterial activity and transaminase activities in the juvenile Japanese flounder, Paralichthys olivaceus. Aquaculture, v.262, p.444-450, 2007.

HOLLAND, M.C.H.; LAMBRIS, J.D. The complement system in teleosts. Fish Shellfish. Immunol., v.12, p.399-420, 2002.

KAJITA, Y.; SAKAI, M.; ATSUTA, S.; KOBAYASHI, M. The immunomodulatory effects of levamisole on rainbow trout, Oncorhynchus mykiss. Fish Pathol., v.25, p.93-98, 1990.

MAGNADOTTIR B. Innate immunity of fish (overview). Fish Shellfish Immunol., v.20, p.137-151, 2006.

MAGNADOTTIR, B.; AUDUNSDOTTIR, S.S.; BRAGASON, B.T.H. et al. The acute phase response of Atlantic cod (Gadus morhua): Humoral and cellular responses. Fish Shellfish. Imunol., v.30, p.1124-1130, 2011.

MAQSOOD, S.; SAMOON, M.H.; SINGH, P. Immunomodulatory and growth promoting effect of dietary levamisole in Cyprinus carpio fingerlings against the challenge of Aeromonas hydrophila. Turk. J. Fish. Aquatic Sci., v.9, p.111-120, 2009.

MARTINS, M.L.; MYIAZAKI, D.M.Y.; TAVARESDIAS, M. et al. Characterization of the acute inflammatory response in the hybrid tambacu (Piaractus mesopotamicus male $\times$ Colossoma macropomum female) (Osteichthyes). Braz. J. Biol., v.69, p.957-962, 2009.

MISRA， C.K.; DAS， B.K.; MUKHERJE， S.C.; PATTNAIK, P. Effect of multiple injections of bglucan on non-specific immune response and disease resistance in Labeo rohita fingerlings. Fish Shellfish Immunol., v.20, p.305-319, 2006.
MISRA, C.K.; DAS, B.K.; MUKHERJEE, S.C. Immune response, growth and survival of Labeo rohita fingerlings fed with levamisole supplemented diets for longer duration. Aquaculture Nutr., v.15, p.356-365, 2009.

MURRAY, C.K.; FLETCHER, T.C. The immunohistochemical localization of lysozyme in plaice (Pleuronectes platessa L.) tissues. J. Fish Biol., v.9, p.329-334, 1976.

NAKANISHI, Y.; KODAMA, H.; MURAI, T. Activation of rainbow trout complement by C-reactive protein. Am. J. Vet. Res., v.52, p.397-401, 1991.

RAO, Y.V.; DAS, B.K.; JYOTYRMAYEE, P.; CHAKRABARTI, R. Effect of Achyranthes aspera on the immunity and survival of Labeorohita infected with Aeromonas hydrophila. Fish Shellfish Immunol., v.20, p.263-273, 2006.

REINHOLD, J.G. Manual determination of serum total protein, albumin and globulin fractions by Biuret method. In: REINER, M. (Ed.). Standard methods in clinical chemistry. New York: Academic Press, 1953. p.88.

SADO, R.Y.; BICUDO, A.J.A.; CYRINO, J.E.P. Dietary levamisole influenced hematological parameters of juvenile pacu, Piaractus mesopotamicus (Holmberg 1887). J. WAS, v.41, p.66-75, 2010.

SALINAS, I.; ZHANG, Y-A.; ORIOL SUNYER, J.O. Mucosal immunoglobulins and B cells of teleost fish. Dev. Comp. Immunol., v.35, p.1346-1365, 2011.

STAFFORD, J.L.; BELOSEVIC, M. Transferrin and the innate immune response of fish: identification of a novel mechanism of macrophage activation. Dev. Comp. Immunol., v.27, p.539-554, 2003.

URBINATI, E.C.; GONÇALVES, F.D.; TAKAHASHI, L.S. Pacu (Piaractus mesopotamicus). In: BALDISSEROTO, B.; GOMES, L.C. (Eds.) Espécies nativas para piscicultura no brasil. 2.ed. Santa Maria: Editora UFSM, 2010. p.205-244.

VANDEPITTE, J.; ENGBAEK, K.; PIOT, P. Métodos básicos de laboratório em bacteriologia clínica. Organização Mundial de Saúde, Genebra. 1993. 122 p.

YANO, T. The nonspecific immune system: Humoral defence. In: IWAMA, G.; NAKANISHI, T. Eds. The Fish Immune System: Organism, Pathogen and Environment. San Diego: Academic Press. 1996. p.105-157. 